IFN Working Paper No. 1194, 2017

\title{
Why Do Military Dictatorships Become Presidential Democracies? Mapping the Democratic Interests of Autocratic Regimes
}

Christian Bjørnskov 


\title{
Why Do Military Dictatorships Become Presidential Democracies?
}

\section{Mapping the Democratic Interests of Autocratic Regimes}

\author{
Christian Bjørnskov* \\ Department of Economics, Aarhus University, Fuglesangs Allé 4, DK-8210 Aarhus V, Denmark; e- \\ mail: chbj@econ.au.dk
}

Research Institute of Industrial Economics (IFN), P.O. Box 55665, S-102 15 Stockholm, Sweden

December 6, 2017

Abstract: This paper starts with the observation that almost all military dictatorships that democratize become presidential democracies. I hypothesize that military interests are able to coordinate on statuspreserving institutional change prior to democratization and therefore prefer political institutions with strong veto players. Parallel civilian interests conversely suffer from coordination failure by being more diverse and les cohesive. The hypothesis therefore implies that most military democratizations are partially planned while most democratization events from civilian autocracy are either unforeseen or poorly planned. Exploring the characteristics of 111 democratization episodes between 1950 and 2015, I find a number of features broadly consistent with further theoretical predictions.

JEL codes: P16, D72, D74, K16

Keywords: dictatorship, democracy, political institutions

\footnotetext{
* I thank Marina Rapp for providing the impetus and some of the first ideas for this paper, and Sascha Becker, Geoffrey Brennan, Michael Dorsch, Stephan Gohmann, Arye Hillman, Jean Lacroix, Martin Rode, Ahmed Skali and participants of the first conference on the Political Economy of Democracy and Dictatorship in Münster (February 2017) and the 10th Australasian Public Choice Conference in Melbourne (December 2017) for comments on earlier versions. I am also grateful to the Jan Wallander and Tom Hedelius Foundation for generous financial support. Needless to say, all remaining errors are entirely my fault.
} 


\section{INTRODUCTION}

Since the 1980s, more than 50 countries have democratized although several democratic regime transitions have proven to be unstable. When communism collapsed in Central and Eastern Europe and the Caucasus, many countries rapidly democratized when they got the chance. Poland and Czechoslovakia held free and fair elections in late 1989 and with the disintegration of the Soviet Union, democracy spread to both the neighbouring Baltic countries and as far as Mongolia. Similarly, the end of the Cold War brought new impetus to African democracy and even earlier, several military dictatorships in Latin America had moved towards democracy.

While a long literature since Lipset (1959) has discussed when societies democratize and whether or not the regime transition is stable, much less attention has been given the particular choice of democratic institutions: Democracy can exist as a presidential or parliamentary system, with one or two chambers, different election procedures and a variety of veto institutions and constitutional differences. The focus of this paper is to explore which type of democracy - and which consequences - may arise when different types of autocracies introduce effectively democratic political institutions.

The starting point of the paper is a peculiar feature that democratization studies seem to have been ignoring so far: When military dictatorships - that is, autocracies in which the political executives have military ranks and backgrounds - democratize, they virtually always turn into presidential democracies. As such, the Latin American tradition of military dictatorship provides an explanation for why most democracies in the region are presidential. Conversely, democratization from either communist or civilian autocracy does not result in a particular type of political institution.

Attempting to make sense of this fact, I develop a model of autocratic democratization. The model rests on the fact that democratization represents a potential threat to the status quo but so does the risk of coups when autocracy is maintained. Democratization thus becomes a choice between competing regime risks. When a move towards democratic political institutions either becomes 
attractive to incumbent elite interests or politically inevitable, the incumbent is likely to attempt to influence the particular design of those institutions such that they best protect the interests of his selectorate. Because military interests are better able to organize a 'constitutional lobby', military dictatorships are therefore more likely to both change constitutional rules prior to democratization and to choose a set-up in which a powerful president can act as a potential status quo-preserving veto player.

A simple comparison of the constitutions and other elements of political institutions after 111 democratization episodes since 1950 reveals a number of features that are broadly consistent with the theory. In particular, military dictatorships have been significantly more likely to introduce new constitutions before democratization while other autocracies were substantially less likely to introduce constitutional changes. Overall, the new constitutions in military dictatorships were likely to resemble what in the United Kingdom came to be called 'the King in Parliament', i.e. institutions in which different political actors hold de facto veto power (cf. North and Weingast, 1989). Further, when a democracy implemented by a military dictatorship collapses, it almost always does so as a result of the military itself retaking power.

The rest of the paper is structured as follows. I first document the main difference between military and non-military democratizations, using Bjørnskov and Rode’s (2017) recent update of the large DD dataset from Cheibub et al. (2010). Section 3 outlines the theoretical framework and sets out the main propositions following from it. In Section 4, I document that several additional differences between military and civilian democratizations are consistent with the theoretical considerations. Section 5 concludes.

\section{MILITARY DICTATORSHIPS BECOME PRESIDENTIAL DEMOCRACIES}

Before proceeding to a theoretical explanation of why certain forms of autocratic regimes might choose different types of democratization, I first document that the main claim upon which the rest of the 
paper rests is factually plausible. Doing so, I rely on the new dataset in Bjørnskov and Rode (2017), which categorizes regime types following the approach in Cheibub et al. (2010). This means that all democracies are categorized as either parliamentary (regime type 0) or two types of presidential institutions depending on whether the president is mostly ceremonial (type 1) or has more direct discretionary power (type 2). Likewise, autocracies are categorized based on the characteristics of the executive: civilian autocracies are separate from military dictatorships in having an executive without a military rank or background (types 3 and 4). Finally, the dataset also includes absolutist monarchy (i.e., royal autocracies; type 5) and colonies. ${ }^{1}$ Table 1 is the transition matrix of the dataset. The overall distinction between democracy and dictatorship is, as in Cheibub et al. (2010), whether or not the country has free and fair elections, as judged by international observers, in which government power can change through peaceful means. ${ }^{2}$

\section{Insert Figure 1 about here}

The table first clearly shows that most regimes are relatively stable, illustrated by the large number of observations along the diagonal. It also illustrates how rarely democracies change type, i.e. how stable constitutional arrangements are once countries are democratic. As long as countries remain democratic, their basic choices of political institutions remain extremely stable. Conversely, the dataset includes 111 regime transitions from some form of autocracy to democracy, of which 32 occurred from a civilian autocracy, 66 from military dictatorship and three from absolutist monarchy.

\footnotetext{
${ }^{1}$ An alternative way of categorizing autocracies, popularized by Geddes (1999), consists in distinguishing between personalist, military and single-party regimes. In the following, most military dictatorships, as categorized by Bjørnskov and Rode (2017), would also be categorized as military by Geddes (1999), and all communist regimes in the following are also single-party. The main difference is that civilian autocracies, in the present category, need not be personal.

${ }^{2}$ It may be worth noting that the particular definition of democracy implies that regimes can transition away from democracy if they implement changes that de facto means that they cannot lose an election. This for example occurred through constitutional amendment in Sri Lanka in 1977 and arguably by fraud in the October 2011 Liberian elections.
} 
The particular feature of this paper is that of the 66 regime transitions from military dictatorship to some form of democracy, only eight resulted in a parliamentary democracy. The transition matrix thus clearly exemplifies the main point of departure of the rest of the paper. In addition, of eight potential examples of non-presidential democratization from military dictatorship, only three - Pakistan on two occasions (1988 and 2008), and Sudan in 1986 - could realistically have introduced a presidential system. The remaining military dictatorships that became parliamentary democracies all share a particular feature: monarchy. Laos and Greece both abandoned monarchy through constitutional change only after having democratized, and Thai democracy has been punctuated by episodes in which the military briefly took power in 1979, 1992 and 2008. However, even the three non-monarchical democratizations are questionable. In the brief episode of Sudanese democracy, the interim constitution defined the head of state as a shared responsibility between a president and four additional members of a state council (Ginsburg et al., 2009). In the case of Pakistan, the political institutions are best categorized as parliamentary, but with the important caveat that the otherwise exclusively ceremonial president retains the formal political control of the military.

The particular military control is also visible in the 36 cases in which the new democracy failed to last for more than a decade. In the 11 cases in which the initial state was a civilian autocracy that democratized, the nature of the autocracy taking over from what must be a fragile democracy was almost random. In six cases, the new regime was again a civilian autocracy while in five cases, the military had taken over and dismantled the democratic institutions. Of the 24 clear cases in which the military had democratized but democracy turned out to be fragile, there is only one case in which it did not happen through a military coup. ${ }^{3}$

\footnotetext{
${ }^{3}$ The single case is Peru in the 1990s where the democratically elected President Alberto Fujimori disregarded the democratic institutions and eventually had to flee the country. After a de facto autocratic interim, the constitutional institutions proved robust enough to re-establish democracy without much ado.
} 
The post-WWII experience thus clearly suggests that democratization from military dictatorship is structurally different than democratization from alternative forms of autocracy. In the following section, I therefore outline a theoretical framework to illustrate the particular characteristics of military democratization. Subsequently I show that additional features of the theoretical framework are also broadly consistent with other known differences between military and civilian democratization episodes.

\section{A THEORY OF OPTIMAL REGIME BEHAVIOUR}

The theoretical model includes three types of agents: ordinary citizens, members of two latent political elites, and potential members of the autocracy. The citizens act as consumers in all political regimes while some (but not all) firms have access to special treatment. The military is a fourth residual agent that receives military spending and may either instigate a coup against the incumbent government or implement democratization.

The theoretical set-up of the political institutions is simple and only captures the most salient features of the decision process around democratization. First, the political institutions of the country are characterized by having two elites that each form a latent selectorate: a relatively cohesive military elite consisting of $\mathrm{q}$ factions, and an industrial elite consisting of $\mathrm{n}$ groups. I assume that $1 \leq \mathrm{q}<\mathrm{n}$ such that the military may be represented by a single cohesive interest group while the industrial elite is always factionalized. Any autocracy can be actively supported by either elite, but not by both at the same time. Within each latent elite, the autocracy must be supported by a minimum coalition, which either represents a majority within the elite or a sufficiently large minority such that no other competing coalition is likely to form. All regimes support each potential selectorate through some form of transfer payments, $\mathrm{m}$ (to the military) and s (to civilian interests).

In the case that the country becomes democratic, two parties either already exist as remainders of whatever electoral system the incumbent autocracy allowed, or are likely to form. Party P is pro-military 
and thus likely to mainly represent the interests of the former military selectorate while Party A is a civilian anti-military party that mainly represents the interests of the former civilian industrial selectorate. While the incumbent autocracy thus always suffers a replacement risk when autocratic, democratization entails another logical risk for any initially incumbent selectorate.

The autocracy can in both situations gain some level of control over the risk. While autocratic, the regime can invest in repression, $\mathrm{r}$, although this type of spending must necessarily be prioritized against other spending: if $\mathrm{m}$ or s are below some threshold, a coalition is likely to form that will attempt a coup against the autocracy. The direct payments to the selectorates $\mathrm{m}$ and $\mathrm{s}$ therefore affect the risk of experiencing a coup attempt - i.e. the extensive margin of the autocratic replacement risk - while $r$ affects the intensive margin, i.e. the likelihood that a coup attempt succeeds. Combined, the two margins thus form the replacement risk, $\mu$, that becomes a function of $\mathrm{m}, \mathrm{s}, \mathrm{r}$ and specific economic factors.

Yet, in order to make sense of the potential transitions between different political regimes, it is necessary to trace the interests of firms and thereby, subsequently, the interests of any potential incumbent. I therefore first outline the main assumptions of firm and individual behaviour before turning to the political interests in the two basic forms of political institutions - autocracy and democracy.

\subsection{Firm, military and individual behaviour}

I first outline how individual consumers, firms and the military behave in the economy. Consumers have standard preferences described by $U$ for a range of goods, $x_{i}$ supplied at price $p_{i}$, and supply one unit of labour inelastically. This yields the maximization problem in 1) where $\mathrm{E}$ is after-tax income defined by a wage $\mathrm{w}$ and an income tax rate $\tau$ such that $\mathrm{w}(1-\tau)$ for ordinary labour - and the $\mathrm{n}^{\text {th }}$ good is the numeraire with $\mathrm{p}_{\mathrm{n}}=1$.

$$
U \equiv \sum_{i=1}^{n} x_{i}^{\beta}
$$




$$
\text { st. } x_{n}+\sum_{i=1}^{n-1} p_{i} x_{i} \leq E
$$

The relative demand for any single good thus becomes:

$$
p_{i}=\left(\frac{x_{i}}{x_{n}}\right)^{\beta-1}
$$

Firm behaviour is given by the assumption that the economy consists of $\mathrm{n}$ firms, each producing a single good, and that each firm has monopolistic power. Each good is produced with only one input - labour, denoted $l_{i}-$ and each firm has its own technology, $a_{i}$, such that some firms are more productive than others. Yet, firms can in principle gain a price subsidy of s percent if they are politically connected in a way defined in the following - one can perhaps best think of this subsidy as an indirect subsidy arising from trade protection (cf. Hillman, 1982; Grossman and Helpman, 1994). Firms pay the wage $\mathrm{w}$ and may incur a cost $\mathrm{c}_{\mathrm{i}}$ in order to be a member of the selectorate group that gets access to the price subsidy. In case they are not part of the selectorate supporting the incumbent government, $\mathrm{s}$ is simply 1 and $\mathrm{c}_{\mathrm{i}}$ is 0 . Firms therefore maximize the profit function in (4), taking their demand functions (3) into account due to their monopolistic power.

$$
\Pi_{i}=s p_{i} a_{i} l_{l}^{\alpha}-w l_{i}-c_{i}
$$

This yields both a choice of how large a workforce to employ, $1_{i}$, and whether or not to incur the cost $\mathrm{c}_{\mathrm{i}}$ of being a member of the selectorate group and getting s. This cost is easily thought of as a coordination or lobbying cost in the tradition of Olson $(1965,1982)$. Employment in industry i thus becomes (5a), which illustrates the distortionary effects of the price subsidy. Solving the optimization problem for industry $\mathrm{n}$ (given in the appendix), which is the numeraire industry and which I assume cannot affect its price level - for example by being subject to either perfect competition conditions or international competition - the labour decision becomes (5b). A comparison between total profits with and without selectorate group membership (and thus the access to the subsidy) yields the membership condition in (6).

$$
l_{i}=\left[\frac{s a_{i}}{x_{n}} \frac{\alpha \beta}{w}\right]^{\frac{1}{\alpha \beta}}
$$




$$
\begin{aligned}
& l_{i}=\left[s \beta a_{i} a_{n}^{\frac{1}{\alpha-1}}\left(\frac{\alpha}{w}\right)^{\frac{1-2 \alpha}{1-\alpha}}\right]^{\frac{1}{\alpha \beta}} \\
& \left.\prod_{i}\right|_{k \in K}>\frac{s^{1-\alpha \beta}}{1-s^{1-\alpha \sigma}}\left(s+c_{i}\right)
\end{aligned}
$$

Equation (6) expresses the necessary price subsidy that would 'buy' support for the incumbent government from a sufficient share of the industrial selectorate. The inequality in (6) thus provides an expression of the minimum price subsidy needed for any industrial interest to support an incumbent government. ${ }^{4}$ In the following, I refer to this sufficient level simply as s*. The definition of sufficiency is that it must yield the support of a subset $\mathrm{K}$ of all $\mathrm{n}$ firms that provides the incumbent regime with an effective selectorate majority. The appendix provides the formal solution for a minimum subsidy that yields increasing profits for the affected firms, and thus an expression of $\mathrm{s}^{*}$ given no coordination costs. This level of $\mathrm{s}$ is increasing in economic and technological development.

Finally, the military has simple preferences for larger spending, as given by the objective function $\mathrm{M}=\mathrm{my}-\mathrm{c}_{\mathrm{m}}$, where $\mathrm{y}$ is total income in society and $\mathrm{c}_{\mathrm{m}}$ is a cost of coordinating on supporting a military regime similar to the $c_{i}$ cost of firms. The military therefore has incentives similar to a stationary bandit, as part of the maximization of $\mathrm{M}$ is also a maximization of taxable income y (cf. Olson, 1982).

\subsection{Optimal policy for autocracies}

\footnotetext{
${ }^{4}$ A further logical extension of this result is that the incumbent government may have a particular interest in choosing a policy mix that, for example, yields sufficient subsidies to a subset of industries - perhaps best thought of as what was once called the 'commanding heights' industries - while achieving the opposite for other industries. This may be thought of as a policy mix in which a subset is protected by high import tariffs while other industries that could potentially form an alternative majority are exposed to free trade. This mix would reduce their profit margin to the extent that they would have little interest in seeking a subsidy - and thus represent a threat to the incumbent - because the coordination cost would be prohibitively high relative to the potential gain.
} 
The main political problem for an autocracy, stated by Tullock (1987) as “The Dictator's Dilemma”, is staying in power. Most policy decisions are therefore aimed primarily at keeping other groups effectively away from power. A regime that aims at staying autocratic must therefore secure direct support either from the military or the industrial selectorate as well as providing repression.

Every government chooses a policy vector $\{\mathrm{m}, \mathrm{s}, \mathrm{r}, \mathrm{a}\}$ where $\mathrm{m}$ is the share of the budget allocated to military spending, $\mathrm{s}$ is spending on industrial policy, $\mathrm{r}$ is spending on repression and $\mathrm{a}$ is residual spending on the autocratic top. All spending is funded by tax revenue such that $\tau=\mathrm{m}+\mathrm{s}+\mathrm{r}$ $+a{ }^{5}$ The optimal policy vector for regimes that plan on staying autocratic must therefore be a combination of paying off interest groups in the military, $\mathrm{m}$, and the industrial selectorate, $\mathrm{s}$, and investing in active repression, $r$, while leaving some residual, a, for whoever is in power. The a-term can perhaps best be interpreted as a combination of luxury accessible to the presidential retinue, the prime minister or top officials and a personal gain from being in power. With any policy vector, total income in society thus becomes (7). The corresponding equilibrium wage $\mathrm{w}$ is given in the appendix.

$$
\begin{aligned}
& y=w+\sum_{k \in K}\left[s^{2} \frac{a_{k}^{1+\alpha \beta} \alpha \beta}{x_{n}^{\beta}} w^{-1}-\left(\frac{s a_{k} \alpha \beta}{x_{n}}\right)^{1-\alpha \beta} w^{1-\alpha \beta}-c_{i}\right]+\sum_{j \notin K}\left[\frac{a_{j}^{1+\alpha \beta}{ }^{1+\alpha \beta} \alpha \beta}{x_{n}^{\beta}} w^{-1}-\right. \\
& \left.\left(\frac{a_{j} \alpha \beta}{x_{n}}\right)^{1-\alpha \beta} w^{1-\alpha \beta}\right]
\end{aligned}
$$

For simplicity, I assume that the objective function of the government takes the particular form in (8) such that the leaders of government gain no utility in the case of a successful coup against them (i.e. when $\mu=1$ ). Further, the set $\mathrm{K}$ includes any industrial interests - i.e. firms - supporting an incumbent civilian autocracy. As such, a last simplification in the following is that $\chi$ will take the value 1 in 'pure' military dictatorships and 0 in pure civilian autocracies. Solving the expressions of the optimal policy vector is thereafter straightforward, yielding what can be thought of as elements of a certainty-

\footnotetext{
${ }^{5} \mathrm{I}$ hold the tax rate $\tau$ constant in order not to introduce an additional source of allocative distortion. However, including the tax rate as an active choice has a similar effect as the price subsidy by allowing larger subsidies while reducing total demand.
} 
equivalent subgame perfect Markov equilibrium. The optimal trade-off is given the first-order condition in the appendix, which translates into the following.

$$
G=(1-\mu) a^{\eta} m^{\chi}\left(\sum_{k \in K} \Pi_{k}\right)^{1-\chi}
$$

Lemma 1: The optimal coup risk for military dictatorship (given in 9) and for civilian autocracies (given in 10) depend on the effectiveness of spending compared to its relative costs in the following way.

$$
\begin{aligned}
\left.\mu\right|_{\chi=1} & =1-\frac{\mu_{m}}{\frac{\chi}{m}-\frac{\beta}{\tau-m-r-s}} \\
\left.\mu\right|_{\chi=0} & =1-\frac{\mu_{s}}{\frac{(1-\chi) \sum_{k \in K} d \Pi_{k} / d s}{\sum_{k \in K} \Pi_{k}}-\frac{\beta}{\tau-m-r-s}}
\end{aligned}
$$

As such, the model illustrates a similar phenomenon to Acemoglu and Robinson's (2006) replacement effect: the risk of observing a successful coup attempt is likely to be decreasing in military spending (for military dictatorships) and industrial support (for civilian autocracies). Yet, it also illustrates that even military dictatorships are likely to have an incentive to invest in buying support through industrial policy, as the optimal risk is also given (with $\chi=1$ ) as (11), which yields the optimal spending allocation for pure military dictatorships in (12).

Proposition 1: Military dictatorships trade off military and civilian threats to power by partially mimicking the industrial policy of civilian autocracies to appease civilian interests.

$$
\begin{aligned}
& \left.\mu\right|_{\chi=1}=1+\frac{\tau-m-s-r}{\beta} \mu_{s} \\
& \left.\mu_{m}\right|_{\chi=1}=\mu_{s}\left(\frac{\tau-m-r-s}{\beta m}-1\right)
\end{aligned}
$$

Again, as both $\mu_{\mathrm{m}}$ and $\mu_{\mathrm{s}}$ must logically be negative, this puts a cap on the size of military spending, $\mathrm{m}$. A level of $\mathrm{m}$ in excess of $\frac{\tau-s-r}{1+\beta}$ will be irrational under all circumstances, as the marginal effect of spending on the probability of regime survival actively turns negative above this maximum level.

It thus remains possible that influential military interests demand spending that a military regime must meet in order to keep a sufficient majority of the military selectorate from finding it profitable to 
attempt to organize a coup, or the costs of the industrial policy that a civilian autocracy must bear in order to keep sufficient majority of the industrial selectorate from finding attempting a coup, are so great that democratization becomes a viable and attractive option. Yet, as Przeworski $(1991,14)$ emphasizes, democratization is to some extent a process of "institutionalizing uncertainty."

\subsection{Optimal democratization - the military perspective}

A necessary part of the main question in this paper is why autocracies choose to democratize, and specifically why military dictatorships do so in a very particular way. Within the same general framework, it is therefore necessary to attempt to trace the interests of regimes that may desire to democratize. Yet, a complication is that democratization need not be a final decision. As experience shows, it remains a possibility that either the democratizing interests or competing interests may want to attempt to re-establish autocracy by ways of a coup if their conditions deteriorate sufficiently under the new democratic institutions.

In order to map the options, I therefore include two types of incentives in the theoretical considerations. First, any incumbent regime has an incentive to choose the type of democratic regime that is most likely to benefit its background support interests. In addition, Bell (2016) argues that it may be tempting for a democratizing regime to impose democratic constraints on the (new) executive, which will inhibit his or her ability to combat a coup attempt. This yields a powerful incentive, which is compatible with the normative foundations of democracy: to design democratic political institutions that do not allow for any form of repression that might be necessary to prevent a coup from happening or succeeding.

I simplify the first type of incentive as a choice between two different institutional forms of democracy. Given that the incumbent autocrat decides to allow democratization, he can first either choose to write a new constitution, or continue with the existing constitution. In both cases, part of the effective change is that the constitution must be respected post-democratization. In case the autocrat 
decides to introduce a new constitution, two basic types of constitutions are possible: 1) either a fully parliamentary political system in which elections to the parliament decide the eventual formation of government and thus the pay-off to the selectorates; or 2) a democratic system with presidential institutions in which the parliament and the president jointly determine the outcome. In the latter case, each selectorate is likely to select a presidential candidate to run for office in separate presidential elections.

The main difference between the two types of democratic political institutions is the probability of having divided government in the presidential system. As such, there are no potential veto players in parliamentary systems, which implies that a parliamentary system is, all other things being equal, the more risky choice. On the other hand, a presidential system will likely resemble what came to be known as "the King in Parliament" after the Glorious Revolution in England in 1688 (North and Weingast, 1989). This type of democratic institution, at its simplest, merely maintains the status quo when the parliamentary majority and the president cannot reach an agreement. As originally stressed by Buchanan and Tullock (1962), bicameral systems entail an implicit supermajority requirement when the two chambers, or in this case the president and the parliament, come to represent different interests. It therefore also reduces the probability of reaching what would be the best possible outcome for an incumbent interest.

If the incumbent autocracy decides to democratize, the regime thus has a second choice to make in the form of the type of democracy. In the case the incumbent autocrat decides not to democratize, the regime is likely to continue unchanged, but with a positive risk $\mu$ of being ousted in a coup. The choice is therefore one of trading off the competing risks inherent in competing institutional choices. The entire decisions structure is illustrated in the game tree in Figure 1.

Insert Figure 1 about here

In the following, I make two main economic assumptions. First, I assume a long run benefit of becoming democratic - a democratic dividend, $\Delta$ - for example through the effects of better judicial 
institutions (cf. North, 1991; Acemoglu and Johnson, 2005; Persson and Tabellini, 2006). Second, I assume that military dictatorships have varied in competence, a term $\xi$ that linearly affects the productivity $a_{i}$ of all firms, such that there is a potential difference between civilian autocracies as well as between different military dictatorships. The competence term $\xi$ is distributed iid around $1{ }^{6}$

I further make two necessary political assumptions: that the risk of the pro-military party losing a parliamentary election, $\theta$, and the risk of the pro-military candidate losing a presidential election, $\varphi$, are determined as (13) and (14). The elections are therefore affected by competence, how well the economy seems to be doing for the median citizen, captured by the income $y_{m}$, and a random term $v$; the appendix provides expressions of the median income. In addition, the choices made by any democratic government are limited by the need to eliminate the risk of being ousted in a coup after the election. As such, this differs from the risk $\mu$ in autocracies because the second incentive for regimes is affected by the assumption that $\mathrm{r}=0$ in democracies. In other words, $\mathrm{I}$ assume that democracies abide by a constitutional ban on direct repression.

$$
\begin{aligned}
& \varphi=e^{-f y_{m}-d \xi-\delta v} \\
& \theta=e^{-g y_{m}-e \xi-\delta v}
\end{aligned}
$$

With respect to the new democratic government, I assume that the winning party continues to represent the interests of the pre-democratization selectorates. This is therefore an assumption of minimal change, which avoids introducing more complicating elements into the democratization decision. As such, the objective function of any government is given by (15). The term $\omega$ captures the probability that the government is elected and gains actual influence, and is therefore simply given by $\theta$

\footnotetext{
${ }^{6}$ The competence term $\xi$ may both encapsulate the competence of the actual leaders, but also the norms of accountability and what is acceptable policy (cf. Bidner and Francois, 2013). It is worth noting that theoretically, military competence (as in equations (18) and (19)) may either increase or decrease the incentive to democratize, as the net effect depends on the coup risk when not democratizing relative to the risk of losing a democratic election.
} 
for party $\mathrm{A}$ in parliamentary systems (and 1- $\theta$ for party $\mathrm{P}$ ) and $\theta \varphi$ for party $\mathrm{A}$ in presidential systems ( $(1-\theta)(1-\varphi)$ for party B).

$$
G=(1-\omega) a^{\eta} m^{\chi}\left(\sum_{k \in K} \Pi_{k}\right)^{1-\chi}
$$

Maximizing $G$ yields the two trade-offs between spending on the military and industrial policy facing parties A and P should they win the election. The solutions yield:

$$
\begin{aligned}
& \left.m\right|_{\chi=1}=\left[\left(\frac{d y_{m}}{d m}-\frac{d y_{m}}{d s}\right) f\right]^{-1} \\
& \left.\sum_{k \in K} \Pi_{k}\right|_{\chi=0}=\frac{d \Pi_{k \in K}}{d s}\left[\left(\frac{d y_{m}}{d s}-\frac{d y_{m}}{d m}\right) f\right]^{-1}
\end{aligned}
$$

However, a potentially important difference occurs in democracies and not autocracies. With two parties (or two coherent blocs), the parties are likely to compete for the support of the median voter. The $y_{m}$ in (13), (14), (16) and (17) refers to the income of the median voter, which may or may not include profits from a firm in the $\mathrm{K}$-set receiving the price subsidy. The term $\mathrm{dy} / \mathrm{dm}$ is simply the tax effect $-\mathrm{Rw} / \mathrm{s}$ where $\mathrm{R}$ is the relative profit share of firms in the K-set - and thus unambiguously negative, which requires the second term of (16) to be negative and larger. For the optimal military spending to be positive - which it must by a margin as shown in (22) $-\mathrm{dy} / \mathrm{ds}$ must be negative and larger; in other words, voters must react sufficiently against the income losses resulting from industrial policy for democratization to be a logical choice.

Comparing the relative pay-offs in all states of the game yields an optimal choice for the military in favour of democratization to a parliamentary system iff (18) holds, and in favour of democratization to a presidential system iff (19) holds:

$$
\begin{aligned}
& m_{0}<\frac{\Delta}{\mu+(1-\mu) \xi}\left[\theta m_{a}+(1-\theta) \xi m_{p}\right] \\
& m_{0}<\frac{\Delta}{\mu+(1-\mu) \xi-(1-\theta) \varphi-(1-\varphi) \theta}\left[\theta \varphi m_{a}+(1-\theta)(1-\varphi) \xi m_{p}\right] \\
& m_{0}>\frac{1}{(1-\theta) \varphi+(1-\varphi) \theta}\left[\theta(1-\varphi) m_{a}+(1-\theta) \varphi \xi m_{p}\right]
\end{aligned}
$$


Rearranging, given that they democratize, the military will prefer a presidential system iff (20) holds. This subsequently yields the requirement that (21) holds if the military prefers firstly to democratize and secondly to do so within a presidential system, which provides the second proposition.

$$
m_{a}<\frac{1-\theta}{\theta} \frac{(1-\theta) \varphi+(1-\varphi) \theta-[\mu-(1-\mu) \xi] \theta}{[\mu-(1-\mu) \xi](1-\varphi)-(1-\theta) \varphi-(1-\varphi) \theta} \xi m_{p}
$$

Proposition 2: When the potential gains from democratization, weighted by the difference between competing risks of losing power in a democracy relative to an autocracy, exceed the risk-weighted loss from democratization, a military dictatorship is likely to democratize with presidential institutions. ${ }^{7}$

Yet, this proposition presupposes that a democratizing military regime peacefully accepts any outcome of the subsequent democratic elections. This begs the question if the military would attempt a coup against the new regime if it resulted in a sufficiently anti-military government? Regardless of the political system, the military would have an interest in a coup iff $m_{0} \mu_{d}+\left(1-\mu_{d}\right) \Delta m_{a}>c_{m}+m_{a}$, i.e. if the expected gain of the coup attempt is larger than the cost of coordinating a coup. Any anti-military party must therefore set military spending according to (22) in order not to experience a coup following the democratization.

$$
m_{a}>\frac{\mu_{d} m_{o}-c_{m}}{1-\left(1-\mu_{d}\right) \Delta}
$$

Entering the minimum military spending that would keep the military from attempting a coup in (20) yields the final proposition.

Proposition 3: If the military is prepared to attempt a coup d'état to reverse democratization outcomes particularly averse to its interests, the military will always prefer democratization with presidential institutions. Proof: see the appendix.

\footnotetext{
${ }^{7}$ An additional result here is that military competence makes it more likely that a presidential system is preferable whenever the condition $(1-\mu) \xi m_{0}<\Delta(1-\theta)(1-\varphi) m_{p}$ holds. This essentially implies the intuitive condition that when the best military spending under autocracy is smaller than the best possible expected military spending under democracy, a more competent military regime will chose to democratize to a presidential system that minimizes its potential loss.
} 
Given the threat of a coup attempt in order to establish (or re-establish) military dictatorship, it thereby always becomes the optimal choice for a military dictatorship to choose a presidential democracy when democratizing. In other words, the combination of the veto institution of presidential democracy and a coup threat is equivalent to a low-cost insurance policy for the military. Yet, whether a coup is likely or not depends on the democratic gain $\Delta$, the coordination costs of the military, and the competence or the likelihood of the coup succeeding. A further final insight here is therefore that setting the minimal $\mathrm{m}_{\mathrm{a}}$ may thus under some conditions keep any anti-military parties from running for election in an otherwise democratic new political system. While the new political institutions are formally democratic, it remains a possibility that a latent coup threat might make it unattractive to the point of irrelevance for anti-military interests to run for office.

\subsection{Optimal democratization - the non-military perspective}

Finally, it is necessary to explore whether the incentive structure behind democratization from a civilian autocracy differs from that of an initial military dictatorship. Figure 1 again provides an overview of the symmetrical decision structure and the potential pay-offs to the selectorate groups. The main difference between a military and civilian autocratic decision nevertheless is that the civilian autocracy, should it choose to democratize, faces two additional, complicating factors.

First, compared to a military regime, the election outcomes also depend on whether or not the interests of the median voter are aligned with firms in the K-set or not. If the median voter does not have a direct stake in the profits of a firm within the K-set, i.e. a firm that is likely to receive the price subsidy, the electoral consequences of increasing the subsidy are larger. A civilian autocracy when democratizing therefore does not necessarily have a parallel interest as the military in implementing veto institutions to maintain the status quo. In the case that the median voter is not aligned with the interests of the initial industrial selectorate majority (the K-set), the civilian regime may have a parallel interest in maintaining the status quo. Yet, in the opposite case, a larger probability of maintaining the 
status quo would run counter to the interests, because democratization here, all other things being equal, would result in a higher subsidy. The main reasons are that the median voter has a comparatively stronger interest in industrial policy - the sign of $\mathrm{dy}_{\mathrm{m}} / \mathrm{ds}$ is ambiguous - and the democratic dividend $\Delta$ as well as the abolition of repression $(\mathrm{r}=0)$ provide larger resources available for funding the subsidy.

Finally, while it can be argued that civilian interests could find it attractive to attempt a coup d'état should the pro-military party win the elections in either system - a risk that is more consequential in a parliamentary system - it remains theoretically uncertain if the potential gain of doing so outweighs the costs of coordinating the $\mathrm{k}$ industrial interests necessary to form an effective selectorate majority. This K-set is thus similar to a minimum winning coalition within the selectorate (cf. Yu and Jong-APin, 2016). Should they be so, a latent civilian coup against the new democracy would be more likely to incentivize a democratization process towards a parliamentary system than a presidential system. In terms of the formal model, the necessary condition for any firm within the initial K-set to participate in a coup attempt against a democracy with a pro-military party at power - even given that its optimal policy is not to provide the subsidy at all $(\mathrm{s}=0)-$ would be a coordination cost $\mathrm{c}_{\mathrm{i}}<\mu_{\mathrm{d}}\left(\mathrm{s}_{0}-\Delta\right)$. Given a large initial subsidy, a small democratic divided and a sufficient probability of a coup succeeding against the new democracy, a civilian latent threat may incentivize democratization towards a parliamentary system. Yet, if this condition is met, it remains a possibility that the comparatively lower coordination costs of a military coup may be sufficiently small to topple either the civilian autocracy or the new democracy in the first place.

In all, while the theoretical considerations suggest that a military incumbent is likely to have clear incentives to choose presidential institutions when democratizing, a civilian incumbent has ambiguous incentives towards the choice of the type of democratic institutions. In the following, I substantiate that this claim, emerging out of a model directed at understanding the unambiguous choice of military dictatorships, is consistent with further facts of democratization episodes since 1950. 


\section{EMPIRICAL INDICATIONS - WHAT IS DIFFERENT IN MILITARY}

\section{DEMOCRATIZATIONS?}

While the model is set up to trace which interests may account for the fact that military dictatorships virtually always choose presidential institutions when democratizing, the theoretical framework also includes a number of implications that should be consistent with further empirical differences between types of democratizations. In addition to employing Bjørnskov and Rode’s (2017) update and elaboration on Cheibub et al. (2010), in the following I use constitutional data from Ginsburg et al. (2009) and the University of Richmond's Constitution Finder (2017), Henisz's (2017) Political Constraints index of veto player strength, and Linzer and Staton's (2015) measure of judicial independence. The appendix outlines the particular variables and sources.

A first implication of the theory is that one would expect to see military dictatorships preparing for democratization by setting up the specific political institutions that appear optimal. A possible mechanism would be to either negotiate a new constitution or significantly amend the existing constitution. One should also expect that the military itself keeps control of this process while a civilian autocracy would be more likely to involve parliamentary institutions. The main assumptions and the outcome of the theoretical considerations also suggest that the military would have stronger preferences for veto institutions and that other parts of the institutional framework would be independent of parliamentary politics. Finally, given that the military coup risk following democratization is supposed to provide mainly stabilizing incentives, one would expect to observe some military coup attempts following a subset of military democratizations.

Table 4 provides indications of political and constitutional differences between democratizations from military dictatorship and civilian autocracy. As a comparison in the right-hand side of the table, the sample is instead split between democratizations from communist and non-communist regimes. The comparisons show that while there is no evidence that one type of democratization is more stable than another, there are other significant differences. 


\section{Insert Table 4 about here}

A first striking difference is that when democratizing, 70 percent of military regimes either amend the constitution or draft a new constitution before the event. Only 12 percent of democratizations from a civilian autocracy - Burundi in 2005, the Dominican Republic in 1966, Pakistan in 1973 and Thailand in 1974, as well as the reinstated constitution in Sudan in 1964 - have introduced a new constitution prior to democratizing. Conversely, many democratizations from civilian autocracy resulted in new or clearly amended constitutions drafted and introduced after the regime change: 30 percent introduced a new constitution that was negotiated after democratization. Among military dictatorships, the same pattern has been rare with only five cases (eight percent) - Brazil in 1988, the Central African Republic in 1994, Greece in 1975, Poland in 1992 and Venezuela in 1961 - where drafting a new constitution was left to the new regime. ${ }^{8}$ Even here, two cases defy clear categorization. The Polish regime prior to democratization is technically categorized (following the coding scheme in Cheibub et al., 2010) as a military dictatorship because the leader - General Wołciech Jaruzelski - had a military rank and position but still headed a communist regime. The Brazilian case also differs due to the special nature of the constitutional draft process in which broad interests within the population were taken into formal account.

In the third of the cases in which a democratizing military dictatorship chose not to write a new constitution, such as Argentina in 1957 and 1963, the existing constitution tended to resemble the constitutions that other military regimes wrote before democratization. These features are broadly consistent with the theoretical outline, which presupposes that the military not only happens upon a presidential democracy, but actively designs it as such.

\footnotetext{
${ }^{8}$ It should be noted that Poland is logically categorized as a military dictatorship because General Wojciech Jaruzelski had taken power in a coup in 1981. It was in all other respects a communist dictatorship, and thus much more similar to a civilian autocracy.
} 
The particular way in which new constitutions were drafted also differs significantly across initially civilian and military regimes. $85 \%$ of the new constitutions in connection with civilian autocracies democratizing were drafted by either the legislature or the executive branch, or with heavy influence from either. In military dictatorships that democratized, the draft process of the more frequent new constitutions tended to be delegated to either a constitutional assembly appointed by the dictatorship or an elected special constitutional legislature assembly. Here, only $44 \%$ of the draft processes included direct influence from either the executive or the legislature. Since 1950, in four cases in which the legislature was somehow involved in the process - Thailand in 1974 and 1978, and Suriname in 1988 and the Republic of Congo in 1992 - and in only one case - Fiji in 1990 - did the legislature alone draft the constitution.

The theoretical outline also suggests that the particular feature of a presidential system is the effective sharing of power between two constitutional actors that both have veto powers. A comparison between the political institutions in new democracies initiated by either the military or a civilian autocracy reveals two further such features. First, while it is extremely rare that the president can formally veto legislation, all but one of the military constitutions allow the president to initiate legislation. This feature is significantly rarer in democracies initiated by civilian autocracies. However, the president in the former type is almost never given the right to not dissolve parliament. In the democracies initiated by civilian autocracies, this feature is approximately twice as likely to be present in the constitution. Second, the number of chambers in parliament also does not differ, but when democratization is accompanied by a constitutional change, approximately half of the changes originating from a civilian autocracy include changing the number of chambers while only 20 percent of those originating from military dictatorships do so $(\mathrm{p}<.05)$. Finally, the constitutions initiated by the military are also significantly more likely to allow the legislature to investigate the president. Although a number of other constitutional features do not differ, the observable differences between the democratic political institutions resulting from military or civilian democratizations yield a consistent 
pattern: consistent with the basis of the theory, the military constitutions clearly tend to create institutions in which the legislature and the president hold relatively equal powers and therefore serve as symmetric veto players for each other. These changes are also visible in the substantially larger increase in political constraints, as measured by Henisz's (2017) PolCon indicator, when the military democratizes.

Yet, before proceeding to any conclusions, two worries need to be settled. The first is that these differences may simply occur because the military also either rigs the institutions or elections such that the first democratically elected president belongs to the prior regime. In other words, does the dictator or his heir apparent carry on into the democratic age? The second is if the assumption that the military keeps an option open for dismantling the new democracy is also reflected in observable actions.

The evidence suggests that the first situation has not generally been the case. The only clear examples of military leaders continuing into a democratic age as central politicians are Jerry Rawlings, who won the democratic elections in Ghana in November 1992 as well as 1996, and Mathieu Kérékou, who won the elections in 1996 after having been the de facto dictator of Benin until 1990 and losing the first democratic elections in 1991. Rawlings retired from the presidency in 2001, as required by the constitution he had himself been instrumental in implementing, and accepted that his main rival five years earlier, John Agyekum Kufuor, won the elections.

Exploring the second question supports the basic theoretical approach. In the ten cases in which a democracy, deriving from a civilian autocracy, experienced a re-autocratization with the first ten years, exactly half were the result of a civilian-led coup and half of a military coup. In the 25 cases in which the military had democratized, 14 of which occurred within the first five years after the event, only one case exists in which the democracy was dismantled by a non-military interest. ${ }^{9}$ The case is Peru in April

\footnotetext{
${ }^{9}$ In addition, it may be worth emphasizing that presidential democracies do not appear more stable than parliamentary types. Although 66 percent of presidential democracies and only $58 \%$ of parliamentary democracies survived the first ten years after democratization, the difference is far from being significant.
} 
1992 when Alberto Fujimori violated his constitutional role by dissolving Congress, suspending the constitution, and purging the judiciary of most opponents of his regime. In all other cases, the military took power within a few years after democratizations that seemingly failed to satisfy its wishes. However, a number of these events also underline the risk of attempting to do so.

The political development of Bolivia from the late 1970s represents a particularly strange example. General David Padilla Arancibia had become president in late 1978 and led a group of prodemocracy officers who eventually restored democracy to Bolivia. Yet, the elections in 1979 did not produce a majority for any presidential candidate, although the strongly leftist Hernán Siles Zuazo received the largest share of voters, and Congress therefore appointed Walter Guevara as president. Guevara held the position for less than three months before General Alberto Natusch performed an apparently successful military coup. His regime would only last 16 days, after which nationwide strikes forced Congress to save military face by appointing Lidia Guelier as interim president until new elections are held. Yet, before the elections, her cousin General Luis García Meza Tejada (who had been promoted to general under the former dictator Hugo Banzer) took power in a bloody coup.

Tejada's dictatorship subsequently got involved in drug trafficking and proved to be extremely violent. After only one year in power, massive international critique pushed García out of office when the military replaced him with General Celso Torrelio Villa. Torrellio Villa failed to restore the reputation of the military regime and for a few days, a military junta instead ruled Bolivia. Eventually, General Guido Vildoso Calderón, who was in charge from July to October 1982, was responsible for the decision to recall the democratically elected 1980 Congress. Hernán Siles Zuazo, the most popular candidate in the 1979 elections, was elected president and went on to serve over an economic disaster until 1985.

The Bolivian example is extreme, but not unrepresentative of many situations after democratization events. It thus remains a final option that the military regimes may perhaps simply exhibit different economic development than the civilian autocracies. Yet, Table B2 in the appendix, 
which exhibits no clear differences in initial GDP per capita, economic growth, openness to trade or structural differences captured by the relative price level on capital goods, suggests otherwise. In summary, a number of additional features surrounding democratizations are roughly consistent with the theoretical explanation of the main feature of this paper: military dictatorships overwhelmingly prefer presidential institutions when choosing to democratize. Although the simple indications in this section do not constitute solid evidence, I nevertheless offer some brief conclusions and suggestions for future research in the final section.

\section{CONCLUSIONS}

This paper set out to provide a theoretical explanation for a particular phenomenon observable in data covering regime changes in the post-WWII period: when military dictatorships democratize, they overwhelmingly choose to do so in the form of presidential democracy while democratizations from other types of autocratic regimes do not exhibit any such regularity.

The theory indicates that in a situation in which both civilian autocracies and military dictatorships choose from a menu of political institutions with which to democratize, both will trade off competing risks. However, the military has substantially stronger preferences because it forms a relatively cohesive interest. Conversely, the civilian / industrial interests supporting a civilian autocracy are less cohesive as they suffer from Olsonian collective action problems (Olson, 1965). In addition, while a pro-military democratic government will be generally supportive of the military, civilian interests may or may not gain from a having an anti-military government. This difference implies that the military is more likely to prefer a political system with strong veto players. The potential threat of a post-democratization coup further reinforces the military interest in a presidential democracy.

A set of indications from the period 1950-2015 support the general theoretical approach. When the military has democratized, it has also historically been much more likely to do so in a planned way by writing a new constitution or substantially amending the existing constitution prior to 
democratization. The military tends to allocate particular powers to the president, as do the circumstances surrounding subsequent coups against the new democracy. In other words, the evidence here suggests that military democratizations in a majority of cases are clearly planned, contrary to the claim in Geddes (1999) that military dictatorships are more prone to regime instability and therefore tend to end in unplanned regime transitions. It is, conversely, consistent with Treisman's (2017) recent argument that most democratization events occurred by mistake, but implies that the mistakes and neglect that leads to random democratization are much more likely in civilian autocracies.

A final question to ask is if the structural differences between the resulting types of democracy are important. Other research suggests so: Persson and Tabellini (1998) for example find that presidential regimes have smaller government sectors, and Bjørnskov and Pfaff (2017) present evidence that military dictatorships repress less than their civilian counterparts, but also that the process of reducing repression after democratization may be slower when democratizing from a military dictatorship. It also remains possible that some regimes are able to repress less or implement other policies if other institutions, such as for example organized religion, support the incumbent regime.

However, most existing studies have tended to treat all autocracies as fundamentally similar although some of the foundational studies of autocracy did not (cf. Tullock, 1987; Wintrobe, 1990). The main finding justifying this paper strongly suggests that they are not, and that more thought should be devoted to how different types of autocracies differ. This paper should merely be considered a humble beginning.

\section{APPENDIX A - THEORY}

As a first, normalizing the total supply of inelastic labour at 1 , and setting total demand for labour at 1 as in (A2), the equilibrium wage rate can be given as (A3a), expressed as a function of labour demand in industry $\mathrm{n}$ in (A1), or the less wieldy expression in (A3b). It is easy to see that increasing the subsidy $\mathrm{s}$ will reduce the wage rate. As it also increases price levels, the overall welfare effect of ordinary citizens 
is unambiguously negative. At the national level, the effect is also negative as the positive effects on profits in firms with the K-set cannot outweigh the negative effects for most citizens due to the adverse effect on overall resource allocation (firms within the K-set come to employ too much labour reallocated from more efficient uses).

$$
\begin{aligned}
& x_{n}=a_{n}^{\frac{1}{1-\alpha}}\left[\frac{\alpha}{w}\right]^{\frac{\alpha}{1-\alpha}} \\
& \sum_{i=1}^{n}\left[\frac{s a_{i} \alpha \beta}{x_{n} w}\right]^{\frac{1}{\alpha \beta}}=1 \\
& w=\frac{x_{n}}{\beta}\left[\sum_{k \in K}\left(s a_{i}\right)^{\frac{1}{\alpha \beta}}+\sum_{k \notin K}\left(a_{i}\right)^{\frac{1}{\alpha \beta}}\right]^{-\alpha \beta} \\
& w=a_{n} \frac{\alpha^{\alpha}}{\beta^{1-\alpha}}\left[\sum_{k \in K}\left(s a_{i}\right)^{\frac{1}{\alpha \beta}}+\sum_{k \notin K}\left(a_{i}\right)^{\frac{1}{\alpha \beta}}\right]^{\alpha \beta(\alpha-1)}
\end{aligned}
$$

Rearranging (5) and (6) and differentiating, it is straightforward to show that the minimum size of the price subsidy s, which will yield a positive effect on profits in supported firms, is given by (A4). Differentiating, the total effects of the price subsidy s on wages are given by (A5). The marginal effect of raising s thus depends both on the relative size of the initial wage and subsidy, but also intuitively on the relative share of total profits - the second fraction - accruing to the supported sectors (the K-set).

$$
\begin{aligned}
& s>\frac{\left(\frac{w}{\alpha \beta}\right)^{1-\alpha(1-\beta)} a_{i}^{\alpha(1-\beta)-\beta}}{(1+\alpha(\beta-1)+1 / \alpha \beta) x_{n}^{(1-\alpha)(1-\beta)}} \\
& \frac{d w}{d s}=-\frac{w}{s} \frac{\sum_{k \in K}\left(s a_{i}\right)^{\frac{1}{\alpha \beta}}}{\sum_{k \in K}\left(s a_{i}\right)^{\frac{1}{\alpha \beta}}+\sum_{k \notin K}\left(a_{i}\right)^{\frac{1}{\alpha \beta}}}
\end{aligned}
$$

As such, any development that either affects the productivity within a 'favoured' industry, i.e. one in the subset $\mathrm{K}$, or a development that affects the productivity of all sectors through the wage rate w, will increase the price of buying support from an industrial selectorate. In other words, for any given tax rate, economic development - whether balanced or not - can undermine the rationale of maintaining a civilian autocracy.

For the firm choices, the first order conditions of equation (7) are given by (A5) to (A7). 


$$
\begin{aligned}
& \mu_{m=}(1-\mu)\left(\frac{\chi}{m}-\frac{\beta}{a}\right) \\
& \mu_{s}=(1-\mu)\left(\frac{(1-\chi) \sum_{k \in K} d \Pi_{k} / d s}{\sum_{k \in K} \Pi_{k}}-\frac{\beta}{a}\right) \\
& \mu_{r}=(1-\mu) \frac{\beta}{a}
\end{aligned}
$$

For the vote outcomes in (13) and (14), the total income is irrelevant. Due to the assumption of median voter politics, the income of the median voter is the relevant measure. (A8) provides the income of the median voter, given that she receives profits from a firm outside of the K-set. (A9) provides the median income for a voter with profit income from a firm within of the K-set, i.e. a firm that provides support for a civilian autocracy / party A and thus also receives the price subsidy.

$$
\begin{aligned}
& y_{m, k \notin K}=w+\frac{a^{1+\alpha \beta} \alpha \beta}{x_{n}^{\beta}} w^{-1}-\left(\frac{a_{i} \alpha \beta}{x_{n}}\right)^{1-\alpha \beta} w^{1-\alpha \beta} \\
& y_{m, k \in K}=w+s^{2} \frac{a^{1+\alpha \beta} \alpha \beta}{x_{n}^{\beta}} w^{-1}-\left(\frac{s a_{i} \alpha \beta}{x_{n}}\right)^{1-\alpha \beta} w^{1-\alpha \beta}-c_{i}
\end{aligned}
$$

The sensitivity of the median incomes to raising the subsidy, i.e. of buying direct support from industrial special interests, is given by (A10) and (A11) where R is defined as the relative share of total profits accruing to the firm associated with the median voter. (A10) and (A11) represent the relevant sensitivities in the policy decisions in (16) and (17). While the sensitivity of $\mathrm{y}_{\mathrm{m}}$ is unambiguously negative when the median voter is not associated with a firm in the K-set, the sensitivity when the median voter is so may under specific circumstances become positive. However, as can be seen in (A11), this requires a sufficiently large subsidy, s, as well as a profit share $\mathrm{R}$ larger than $\alpha \beta /(1-\alpha \beta)$.

$$
\begin{aligned}
& \frac{d y_{m, k \notin K}}{d s}=-\frac{R_{k \notin K}}{s}\left[w+\frac{a^{1+\alpha \beta} \alpha \beta}{x_{n}^{\beta}}+(1-\alpha \beta)\left(\frac{a_{i} \alpha \beta}{x_{n}}\right)^{1-\alpha \beta} w^{1-\alpha \beta}\right] \\
& \frac{d y_{m, k \in K}}{d s}=\frac{R_{k \in K}}{R_{k \notin K}} \frac{d y_{m, k \notin K}}{d s}+2 \frac{s}{w} \frac{a^{1+\alpha \beta} \alpha \beta}{x_{n}^{\beta}}-(1-\alpha \beta) s^{-\alpha \beta}\left(\frac{a_{i} \alpha \beta}{x_{n}}\right)^{1-\alpha \beta} w^{1-\alpha \beta}
\end{aligned}
$$


Insert Table B1 about here

Insert Table B2 about here

\section{REFERENCES}

Acemoglu, Daron and Simon Johnson. 2005. Unbundling institutions. Journal of Political Economy, 113, 949-997.

Acemoglu, Daron, Davide Ticchi, and Andrea Vindigni. 2010. A theory of military dictatorships.

American Economic Journal: Macroeconomics, 2, 1-42.

Beck, Thorsten, George Clarke, Alberto Groff, Philip Keefer and Patrick Walsh. 2001. New tools and new tests in comparative political economy: the database of political institutions. World Bank Economic Review, 15, 165-176.

Bell, Curtis. 2016. Coup d'état and democracy. Comparative Political Studies, 49, 1167-1200.

Bidner, Chris and Patrick Francois. 2013. The emergence of political accountability. Quarterly Journal of Economics, 128, 1397-1448.

Bjørnskov, Christian and Katharina Pfaff. 2017. The effect of coups d'état on physical integrity rights. Working paper, Aarhus University.

Bjørnskov, Christian and Martin Rode. 2017. Regimes and regime transitions: A new dataset. Working paper, Aarhus University.

Bjørnskov, Christian and Stefan Voigt. 2016. Why do governments call a state of emergency? On the determinants of using emergency constitutions. Paper presented at the annual conference of the European Association of Law and Economics (Bologna), September 15-17.

Buchanan, James M. and Gordon Tullock. 1962. The Calculus of Consent: Logical Foundations of Constitutional Democracy. Ann Arbor: University of Michigan Press. 
Bueno de Mesquita, Bruce, Alastair Smith, Randolph M. Siverson and James D. Morrow. 2003. The logic of political survival. Cambridge: MIT Press.

Cheibub, José A., Jennifer Gandhi and James R. Vreeland. 2010. Democracy and dictatorship revisited. Public Choice, 143, 67-101.

Fish, M Steven and Matthew Kroenig. 2009. The Handbook of National Legislatures: A Global Survey.

Cambridge: Cambridge University Press.

Geddes, Barbara. 1999. What do we know about democratization after twenty years? Annual Review of Political Science, 2, 115-144.

Ginsburg, Tom, Zachary Elkins and James Melton. 2009. The Endurance of National Constitutions.

Cambridge: Cambridge University Press.

Grossman, Gene M. and Elhanan Helpman. 1994. Protection for sale. American Economic Review, 84, 833-850.

Heston, Alan, Robert Summers and Betina Aten. 2012. Penn World Tables Version 7.1. Philadelphia, PA: Center for International Comparisons of Production, Income, and Prices, University of Pennsylvania.

Henisz, Witold. 2017. Political Constrains Index (PolCon) Dataset. University of Pennsylvania; dataset and codebook available at https://whartonmgmt.wufoo.com/forms/political-constraint-index-polcondataset/ (accessed January 2017).

Hillman, Arye L. 1982. Declining industries and political-support protectionist motives. American Economic Review, 72, 1180-1187.

Linzer, Drew A. and Jeffrey K. Staton. 2015. A global measure of judicial independence, 1948-2012. Journal of Courts and Law, 3, 223-256.

North, Douglass. 1991. Institutions. Journal of Economic Perspectives, 5, 97-112. 
North, Douglass and Barry Weingast. 1989. Constitutions and commitment: The evolution of institutions governing public choice in seventeenth-century England. Journal of Economic History, 49, 803832.

Olson, Mancur. 1965. The Logic of Collective Action: Public Goods and the Theory of Groups. Cambridge, MA: Harvard University Press.

Olson, Mancur. 1982. The Rise and Decline of Nations: Economic Growth, Stagflation, and Social Rigidities. New Haven, CT: Yale University Press.

PARLINE. 2016. Database on national parliaments. http://www.ipu.org/parline-e/parlinesearch.asp (accessed December 2016).

Persson, Torsten and Guido Tabellini. 1999. The size and scope of government: comparative politics with rational politicians. European Economic Review, 43, 699-735.

Persson, Torsten and Guido Tabellini. 2006. Democracy and development. The devil is in the details. American Economic Review Papers and Proceedings, 96, 319-324.

Przeworski, Adam. 1991. Democracy and the Market: Political and Economic Reforms in Eastern Europe and Latin America. New York: Cambridge University Press.

Rode, Martin and James D. Gwartney. 2012. Does democratization facilitate economic liberalization? European Journal of Political Economy, 28, 607-619.

Treisman, Daniel. 2017. Democracy by mistake. NBER working paper no. 23944.

Tullock, Gordon. 1987. Autocracy. Dordrecht: Klüwer.

Vreeland, James R. 2008. The effect of political regime on civil war: unpacking anocracy. Journal of Conflict Resolution, 52, 401-425.

Wintrobe, Ronald. 1990. The tinpot and the totalitarian: An economic theory of dictatorship. American Political Science Review, 84, 849-872.

Yu, Shu and Richard Jong-A-Pin. 2016. Political leader survival: does competence matter? Public Choice, $166,113-142$. 
Table 1. Transition matrix 1950-2015

\begin{tabular}{|c|c|c|c|c|c|c|c|c|}
\hline & & & & & ime typ & & & \\
\hline & & 0 & 1 & 2 & 3 & 4 & 5 & Colony \\
\hline & 0 & 2190 & 3 & 0 & 10 & 8 & 3 & 21 \\
\hline & & $(-)$ & (18.8) & $(0.0)$ & (9.4) & $(6.9)$ & $(21.4)$ & $(18.9)$ \\
\hline & 1 & 3 & 866 & 1 & 15 & 17 & 0 & 1 \\
\hline 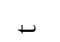 & & (11.1) & $(-)$ & $(2.9)$ & $(14.2)$ & (14.8) & $(0.0)$ & $(0.9)$ \\
\hline$\ddot{\Xi}$ & 2 & 0 & 1 & 1274 & 17 & 41 & 0 & 2 \\
\hline 蒠 & & $(0.0)$ & $(6.3)$ & $(-)$ & $(16.0)$ & (35.7) & $(0.0)$ & (1.8) \\
\hline 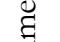 & 3 & 3 & 5 & 8 & 2616 & 49 & 6 & 57 \\
\hline है & & (11.1) & $(31.3)$ & $(23.5)$ & $(-)$ & $(42.6)$ & $(42.9)$ & $(52.3)$ \\
\hline & 4 & 20 & 7 & 25 & 63 & 1542 & 5 & 0 \\
\hline & & $(74.1)$ & $(43.8)$ & $(73.5)$ & (59.4) & $(-)$ & $(35.7)$ & $(0.0)$ \\
\hline & 5 & 1 & 0 & 0 & 1 & 0 & 935 & 29 \\
\hline & & $(3.7)$ & $(0.0)$ & $(0.0)$ & $(0.9)$ & $(0.0)$ & $(-)$ & $(26.1)$ \\
\hline
\end{tabular}

Note: numbers in parentheses are percent of all changes in a given regime type. 
Table 2. Military democratizations

\begin{tabular}{|c|c|c|c|}
\hline Transition to parliamentary & Transition to mixed & Transition to presidential & Transition to presidential \\
\hline Fiji, 1992 (yn) & Bangladesh, 1986 (yy) & Argentina, 1957 (nn) & Honduras, 1957 (yn) \\
\hline Ghana, 1969 (nn) & Central Afr. Rep., 1993 (yn) & Argentina, 1963 (nn) & Honduras, 1971 (nn) \\
\hline Greece, 1974 (yy) & Rep. of Congo, 1992 (yn) & Argentina, 1973 (nn) & Honduras, 1982(yy) \\
\hline Laos, 1951 (yn) & Guinea-Bissau, 2001 (nn) & Argentina, 1983(yy) & Indonesia, 1999 (yy) \\
\hline Pakistan, 1988 (yy) & Madagascar, 1993 (yy) & Benin, 1991 (yy) & Korea, 1988 (yy) \\
\hline Pakistan, $2008(\mathrm{y}-)$ & Mali, 1992 (yy) & Bolivia, 1979 (nn) & Nigeria, 1979 (nn) \\
\hline Sudan, 1986 (nn) & Mali, $2014(--)$ & Bolivia, 1982 (yy) & Nigeria, 1999 (уy) \\
\hline Thailand, 1979 (nn) & Mauritania, 2007 (nn) & Brazil, 1985 (yy) & Panama, 1952 (yy) \\
\hline Thailand, 1992 (yy) & Niger, 1993 (nn) & Burundi, 1993 (nn) & Panama, 1990 (yy) \\
\hline \multirow[t]{12}{*}{ Thailand, 2008 (yn) } & Niger, 2000 (yy) & Chile, 1990 (yy) & Paraguay, 1989 (yy) \\
\hline & Niger, $2011(y-)$ & Colombia, 1958 (yy) & Peru, 1956 (yn) \\
\hline & Poland, 1989 (yy) & Comoros, 2004 (yy) & Peru, 1964 (yn) \\
\hline & Portugal, 1976 (yy) & Ecuador, 1979 (yy) & Peru, 1980 (yy) \\
\hline & Turkey, 1961 (yy) & El Salvador, 1984 (yy) & Sierra Leone, 1996 (nn) \\
\hline & Turkey, 1983 (yy) & Ghana, 1979 (nn) & Sierra Leone, 1998 (yy) \\
\hline & & Ghana, 1993 (yy) & Suriname, 1988 (nn) \\
\hline & & Guatemala, 1958 (yn) & Suriname, 1991 (yy) \\
\hline & & Guatemala, 1966 (yy) & Tunisia, $2012(--)$ \\
\hline & & Guatemala, 1986 (yy) & Uruguay, 1985 (yy) \\
\hline & & Guinea, $2011(y-)$ & Venezuela, 1959 (yy) \\
\hline & & Guinea-Bissau, 2014 (--) & \\
\hline
\end{tabular}

Note: Bhutan (2007) and Nepal (1990) democratized from states of absolutist monarchy. The countries marked by italics were monarchies. The parentheses denote whether the democracy proved stable for the first five years (first y for yes, or $n$ for no) and the first ten years (second $y$ and $n$ ). 
Table 3. Non-military democratizations

\begin{tabular}{llll}
\hline Transition to parliamentary & Transition to mixed & Transition to presidential & Transition to presidential \\
\hline Albania, 1991 (yy) & Bulgaria, 1990 (yy) & Burundi, 2005 (yn) & Mexico, 2000 (yy) \\
Czechoslovakia, 1989 (yy) & Cabo Verde, 1991 (yy) & Cyprus, 1983 (yy) & Nicaragua, 1984 (yy) \\
Grenada, 1984 (yy) & Comoros, 1990 (yn) & Dominican Rep., 1966 (yy) & Peru, 2001 (yy) \\
Hungary, $1990(\mathrm{yy})$ & Georgia, 2004 (yy) & Ecuador, 2002 (yy) & Philippines, 1986 (yy) \\
Korea, 1960 (nn) & Guinea-Bissau, 2004 (yn) & Guyana, 2012 (--) & Sri Lanka, 1989 (yy) \\
Lesotho, 2012 (--) & Kyrgyzstan, 2005 (yn) & Kenya, 1998 (yy) & Uganda, 1980 (yn) \\
Spain, 1977 (yy) & Kyrgyzstan, 2012 (--) & Liberia, 2006 (yn) & Zenezuela, 2001 (yy) \\
Sudan, 1965 (nn) & Malaysia, 2009 (y-) 2012 (--) \\
Thailand, 1975 (nn) & Mongolia, 1990 (yy) & Malawi, 1994 (yy) & Maldives, 2008 (yn) \\
& Pakistan, 1973 (yn) & & \\
& Romania, 1990 (yy) & & \\
& Sao Tomé, 1991 (yy) & & \\
& Senegal, 2000 (yy) & & \\
& Serbia, 2000 (yy) & & \\
& Taiwan, 1996 (yy) & & \\
& (1) & & \\
&
\end{tabular}

Note: Bhutan (2007) and Nepal (1990) democratized from states of absolutist monarchy. The countries marked by italics were monarchies. The parentheses denote whether the democracy proved stable for the first five years (first y for yes, or $n$ for no) and the first ten years (second y and n). 
Table 4. Differences in constitutions and political institutions

\begin{tabular}{|c|c|c|c|c|}
\hline & Military & Civilian & Non-communist & Communist \\
\hline New constitution & $\begin{array}{c}.61 \\
(p<.00)\end{array}$ & .15 & $\begin{array}{c}.44 \\
(\text { p. }<05)\end{array}$ & .11 \\
\hline $\begin{array}{l}\text { Constitutional } \\
\text { amendment }\end{array}$ & $\begin{array}{c}.08 \\
(\mathrm{p}<.08)\end{array}$ & .21 & $\begin{array}{c}.56 \\
(\mathrm{p}<.00)\end{array}$ & .13 \\
\hline Legislative influence & $\begin{array}{c}.44 \\
(p<.01)\end{array}$ & .86 & $\begin{array}{c}.83 \\
(p<.19)\end{array}$ & .55 \\
\hline Time since last election & $\begin{array}{c}5.3 \\
(p<.41)\end{array}$ & 6.2 & $\begin{array}{c}5.6 \\
(p<.39)\end{array}$ & 4.1 \\
\hline $\begin{array}{l}\text { Democracy stable next } \\
5 \text { years }\end{array}$ & $\begin{array}{c}.75 \\
(p<.10)\end{array}$ & .90 & $\begin{array}{c}.80 \\
(p<.14)\end{array}$ & 1 \\
\hline $\begin{array}{l}\text { Democracy stable next } \\
10 \text { years }\end{array}$ & $\begin{array}{c}.59 \\
(p<.76)\end{array}$ & .62 & $\begin{array}{c}.59 \\
(p<.02)\end{array}$ & 1 \\
\hline $\begin{array}{l}\text { Presidential power } \\
\text { index }\end{array}$ & $\begin{array}{c}4.33 \\
(p<.75)\end{array}$ & 4.27 & $\begin{array}{c}4.32 \\
(p<.06)\end{array}$ & 3.50 \\
\hline $\begin{array}{l}\text { Presidential power } \\
\text { uncertainty }\end{array}$ & $\begin{array}{c}3.39 \\
(p<.23)\end{array}$ & 2.99 & $\begin{array}{c}3.23 \\
(p<.03)\end{array}$ & 4.79 \\
\hline Legislative power index & $\begin{array}{c}3.16 \\
(p<.57)\end{array}$ & 2.96 & $\begin{array}{c}3.09 \\
(p<.08)\end{array}$ & 3.89 \\
\hline Initiate legislation & $\begin{array}{c}.96 \\
(p<.00)\end{array}$ & .65 & $\begin{array}{c}.85 \\
(p<.22)\end{array}$ & 1 \\
\hline Veto legislation & $\begin{array}{c}.08 \\
(.33)\end{array}$ & .15 & $\begin{array}{c}.11 \\
(p<.97)\end{array}$ & .11 \\
\hline Challenge legislation & $\begin{array}{c}.45 \\
(p<.89)\end{array}$ & .42 & $\begin{array}{c}.44 \\
(p<.52)\end{array}$ & .56 \\
\hline $\begin{array}{l}\text { Investigation by } \\
\text { legislature }\end{array}$ & $\begin{array}{c}.89 \\
(p<.03)\end{array}$ & .67 & $\begin{array}{c}.78 \\
(\mathrm{p}<.79)\end{array}$ & .82 \\
\hline Amendment rights & $\begin{array}{c}.41 \\
(p<.89)\end{array}$ & .38 & $\begin{array}{c}.40 \\
(p<.13)\end{array}$ & .67 \\
\hline Dissolution power & $\begin{array}{c}.37 \\
(p<.02)\end{array}$ & .67 & $\begin{array}{c}.47 \\
(p<.09)\end{array}$ & .78 \\
\hline Length of constitution & $\begin{array}{l}22,717 \\
(p<.67)\end{array}$ & 24,346 & $\begin{array}{l}23,321 \\
(p<.02)\end{array}$ & 10,127 \\
\hline $\begin{array}{l}\text { Political constraints, } \\
\text { post-change }\end{array}$ & $\begin{array}{c}.31 \\
(\mathrm{p}<.72)\end{array}$ & .31 & $\begin{array}{c}.31 \\
(\mathrm{p}<.03)\end{array}$ & .44 \\
\hline$\Delta$ political constraints & $\begin{array}{c}.27 \\
(\mathrm{p}<.02)\end{array}$ & .17 & $\begin{array}{c}.24 \\
(\mathrm{p}<.00)\end{array}$ & .44 \\
\hline $\begin{array}{l}\text { Judicial independence, } \\
\text { post-change }\end{array}$ & $\begin{array}{c}.39 \\
(\mathrm{p}<.10)\end{array}$ & .46 & $\begin{array}{c}.42 \\
(\mathrm{p}<.02)\end{array}$ & .57 \\
\hline$\Delta$ judicial independence & $\begin{array}{c}.09 \\
(p<.75)\end{array}$ & .09 & $\begin{array}{c}.09 \\
(p<.00)\end{array}$ & .21 \\
\hline
\end{tabular}


Table B1. Variables and sources

\begin{tabular}{|c|c|c|}
\hline Variable & Definition & Source \\
\hline New constitution & $\begin{array}{l}\text { Dummy, new constitution written before } \\
\text { democratization event }\end{array}$ & Ginsburg et al. (2009) \\
\hline Constitutional amendment & $\begin{array}{l}\text { Dummy, constitution amended written before } \\
\text { democratization event }\end{array}$ & Ginsburg et al. (2009) \\
\hline Legislative influence & Dummy, new constitution drafted & \\
\hline Time since last election & Years since last elections prior to democratization & PARLINE (2016) \\
\hline $\begin{array}{l}\text { Democracy stable next } 5 \\
\text { years }\end{array}$ & $\begin{array}{l}\text { Dummy, democratic all five years after } \\
\text { democratization }\end{array}$ & Bjørnskov and Rode (2017) \\
\hline $\begin{array}{l}\text { Democracy stable next } 10 \\
\text { years }\end{array}$ & $\begin{array}{l}\text { Dummy, democratic all ten years after } \\
\text { democratization }\end{array}$ & Bjørnskov and Rode (2017) \\
\hline Presidential power index & $\begin{array}{l}\text { Additive index capturing whether president has } \\
\text { power to approve amendments to constitution, } \\
\text { issue decrees, pardon convicted felons, declare or } \\
\text { approve emergencies, suspend basic rights during } \\
\text { emergencies, approve legislation, and is immune } \\
\text { from prosecution }\end{array}$ & Own \\
\hline $\begin{array}{l}\text { Presidential power } \\
\text { uncertainty }\end{array}$ & $\begin{array}{l}\text { Additive index of how many elements in the } \\
\text { presidential power index are constitutionally } \\
\text { uncertain }\end{array}$ & Own \\
\hline Legislative power index & $\begin{array}{l}\text { Additive index of } 15 \text { elements of discretionary } \\
\text { power of legislature, following Fish and Kroenig's } \\
\text { (2009) Parliamentary Powers Index }\end{array}$ & Bjørnskov and Voigt (2016) \\
\hline Initiate legislation & $\begin{array}{l}\text { Dummy, is the president allowed to initiate } \\
\text { legislation }\end{array}$ & Ginsburg et al. (2009) \\
\hline Veto legislation & Dummy, can the president to veto legislation & Ginsburg et al. (2009) \\
\hline Challenge legislation & & Ginsburg et al. (2009) \\
\hline Investigation by legislature & $\begin{array}{l}\text { Dummy, can the president be investigated by the } \\
\text { legislature }\end{array}$ & Ginsburg et al. (2009) \\
\hline Amendment rights & Dummy, is the president allowed to amend rights & Ginsburg et al. (2009) \\
\hline Dissolution power & $\begin{array}{l}\text { Dummy, does the constitution allow the } \\
\text { dissolution of parliament in emergencies }\end{array}$ & Ginsburg et al. (2009) \\
\hline Length of constitution & $\begin{array}{l}\text { Number of words (in English translation) of the } \\
\text { constitution }\end{array}$ & Ginsburg et al. (2009) \\
\hline $\begin{array}{l}\text { Political constraints, post- } \\
\text { change }\end{array}$ & $\begin{array}{l}\text { Index of political constraints on executive after } \\
\text { democratization }\end{array}$ & Henisz (2017) \\
\hline$\Delta$ political constraints & Change in political constrains at democratization & Henisz (2017) \\
\hline $\begin{array}{l}\text { Judicial independence, post- } \\
\text { change }\end{array}$ & $\begin{array}{l}\text { Index of how independent the judiciary is from } \\
\text { the legislature and executive }\end{array}$ & Linzer and Statton (2015) \\
\hline$\Delta$ judicial independence & $\begin{array}{l}\text { Change in judicial independence at } \\
\text { democratization }\end{array}$ & Linzer and Statton (2015) \\
\hline GDP per capita at event & Real GDP per capita in year of democratization & Heston et al. (2012) \\
\hline $\begin{array}{l}\text { Growth differential, } 3 \text { yrs } \\
\text { post-prior }\end{array}$ & $\begin{array}{l}\text { Change in real GDP per capita from three years } \\
\text { prior to democratization to three years after }\end{array}$ & Heston et al. (2012) \\
\hline Openness differential & $\begin{array}{l}\text { Change in openness (trade volume) from three } \\
\text { years prior to democratization to three years after }\end{array}$ & Heston et al. (2012) \\
\hline Investment price differential & $\begin{array}{l}\text { Change in price level of capital goods from three } \\
\text { years prior to democratization to three years after }\end{array}$ & \\
\hline
\end{tabular}


Table B2. Economic differences

\begin{tabular}{lcccc}
\hline & Military & Civilian & Non-communist & Communist \\
\hline GDP per capita at event & 3634 & 4111 & 3803 & 6646 \\
Growth differential, 3 & $(\mathrm{p}<.52)$ & & $(\mathrm{p}<.04)$ & -004 \\
yrs post-prior & -.09 & 1.34 & $(\mathrm{p}<.01)$ & 1.90 \\
Openness differential & $(\mathrm{p}<.29)$ & & 1.09 & 1.10 \\
& 1.07 & 1.14 & $(\mathrm{p}<.94)$ & 1.12 \\
Investment price & $(\mathrm{p}<.19)$ & .99 & $(\mathrm{p}<.02)$ & \\
differential & 1.05 & & & \\
\hline
\end{tabular}


Figure 1. The decision structure

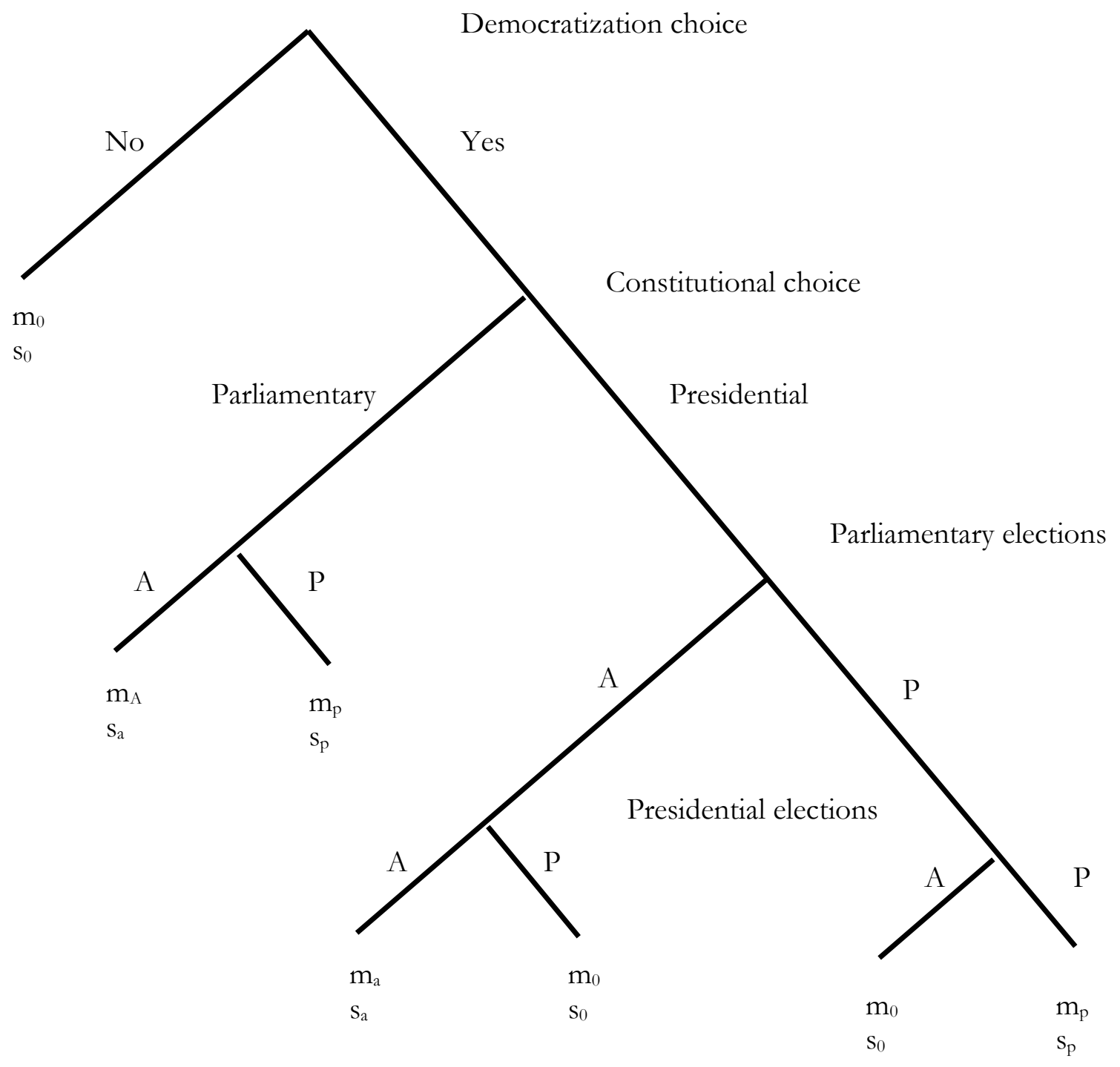

